\title{
Child Schooling and Child Work in India: Does Poverty Matter?
}

\author{
Bijaya Kumar Malik \\ National Council of Educational Research and Training \\ India
}

This paper examines the differentials of school attendance patterns. i.e. never attended, entered into school, dropout rate, repeating, left school two or more years ago and child work by economic condition of household in India. The wealth index is used to understand the economic differentials in child schooling of households. The study findings suggest that children belonging to the poorest wealth quintile of households are significantly more likely never to have attended school, have higher dropout rates and be over-age compared to children belonging to wealthier and the wealthiest quintiles. The states' differentials in child school attendance patterns showed that the state of Bihar has the highest proportion of children never having attended compared to lowest proportion for Kerala (39 percent vs. 2 percent). The working children among poor households are more deprived to attend school compared to children from wealthier households. This paper concludes that economic conditions of the household are the main determinant of child schooling in India.

Key words: child work, poverty, never attended, drop out, wealth index

\section{Introduction}

The literacy rate in India increased from 65 percent in 2001 to 74 percent by 2011(Census of India, 2011). The increase in literacy rate was observed across gender, residence and districts of India. The female literacy was higher than

Correspondence concerning this report should be addressed to Bijaya Kumar Malik, Assistant Professor, Department of Education in Social Sciences, National Council of Educational Research and Training, Sri -Aurovindo Marg, New Delhi, Pin-110016, India. Electronic mail may be sent to bijayancert@gmail.com males in both rural and urban settings. The improvement in literacy rate in rural settings is two times more than urban settings during that period. The increase in literacy rate is the outcome of various central and state government schemes for universalization of primary education. Out of all educational policies for initiated by India recently, the Right to Education (RTE) Act implemented by the government has called for all children up to 14 years of age to receive free and compulsory education in Indian states. This act is also known as Right of Children to Free and Compulsory Education Act (RTE) 2009. 
RTE provides flexibility in that it will safe guard needy children in all sections of our society, creating a school friendly environment in all aspects of schooling irrespective of socioeconomic status. For those children who have not completed their elementary education, RTE will also provide special provision for their further education, with an aim of reducing the retention rate (Minitry of Human Resource Development [MHRD], 2009). Across the world, countries have realized that the quality and universalization of primary education is important to success in multiple aspects of social and other areas of development for any nation. Further, India's National Policy of Education (NPE, 1968, 1986, 1992) has given momentum to higher student achievement, classroom quality and achievement of universalization of elementary education. The Sarva Siksha Abhiyan (SSA) in India, launched during 2001-02 is working effectively to provide elementary education to all children. The Millennium Development Goals (MDGs) promoted by the United Nations are committed to achieving the goal of universal primary education under goal 2 by 2015 for all countries.

\section{Review of Literature}

Various research studies have examined the socio-economic differentials in child schooling in Indian context. Enrolment in primary education has increased in last the 14 years (Rajaram \& Jayachadran,
2007). Small-scale studies in rural Odisha had shown that children belonging to chronically poor households are less likely to attend school and more likely to work in rural areas of India (Malik \& Mohanty, 2009). The cost of schooling also influences the rate of school continuation (Hazarika \& Arjun, 2006). The distance of schools from households, lack of interested in studies and the need for children to perform outside work for cash payment are main reasons for children dropping out of school (IIIS \& Macro International, 2007). Economic opportunity in urban India for rural children is also contributing the dropout rate of child schooling among poor household children (Edmonds, Pavcnik, \& Topalova, 2008). Households having more children are less interested to continue school for each child compared to households with fewer children (Montgomery et al., 1995). School enrolment in India has increased substantially irrespective of regions and socio-economic conditions (Filmer \& Pritchett, 1999). Seventy percent of children in India are undernourished and anaemic (Save the Children Report, 2012) and India is behind Pakistan, Sri Lanka, and Bangladesh in nutritional status among studied countries (Times of India, 2012). Disadvantaged children have limited access to music, art and out-of-school activities compared to rich children (Gortte et al., 2007). Children are at great risk of experiencing exclusion within school due to poverty in their household (Ridge, 2002). Poverty is 
clearly a risk factor for children's poor development and limited educational outcomes, and it may be that risk in the early years will continue to have an effect even if the family moves out of poverty later in the child's life (Patrice et al., 2008). Due to deprivation there is limited access to good education and less participation in elementary education (Chaudhuri \& Jha, 2011). Longer periods of poverty in families, non-availability of and poor accessibility to schools in the locality and lack of proper transportation have forced many children to leave the school and work in hazardous situations (Times of India, 2012). Children from disadvantaged households perform poorly (low scores) compared to peers from more advantaged backgrounds (New York Times, 2011). The magnitude, depth, duration and timing of poverty influence a child's educational attainment in all section of society (Ferguson, Bovaird, \& Muller, 2007). Children from poor households are late to receive schooling, experience more drop-out and work during study, irrespective of castes and religion (Malik \& Mohanty, 2009). Family income is the most important determinant of child and adolescent education and wellbeing (Brooks-Gunn \& Duncan, 1997). Socioeconomic status (SES) is the single strongest predictor of child schooling and achievement in school and there are various negative influences due to low SES on children's overall development (Levin, 2007). Children living in poverty are more likely to perform poorly in school examinations and they are prone to leave school without getting any special skill for their future life (Murnane, 2007). Children from lowincome minority families have lower educational outcomes and developmental engagement compared to children in wealthier families (Leventhal, Fauth, \& Brooks-Gunn, 2005). Family income and poverty status are powerful key factors for determining educational, cognitive and behavioral attainment (Duncan, Brooks-Gunn, \& Klebanov, 1994).

\section{Rationale for the Study}

The child and adolescent population constitutes a substantial proportion (42 percent) of India's total population, numbering nearly 440 million (Census of India, 2001). India is home to 243 million adolescents compared to 200 million in China - more than any other country in the world (The United Nations Children's Fund [UNICEF], 2012). They will constitute the largest generation in history to make the transition from childhood to adulthood and this transition will be a key to the country's long-run development in terms of human resources. Education plays a pivotal role in every aspect of life, development of any society and reduction in crime. Therefore we have to ensure and steps are taken towards achieving one hundred percent primary and secondary education for this huge cohort of our population and ensure it is done in a healthy and quality manner. These children deserve access to quality 
education, guidance and care, as well as the opportunities to realize their full potential However, although we have enormous population of children in our country, there are critical demographic concerns that are very challenging. Retention in primary school is only 71 percent for all students and 48 percent for girls (National University of Educatonal Planning and Administraton [NUEPA], 2005). About 46 percent of children are born with low birth weight and 79 percent of children under three years of age are anaemic (IIPS \& Macro International, 2007). Nearly seventy percent of children are physically abused and 53.22 percent of children are sexually abused in one form or another (Ministry of Women and Child Development Government of India [MoWCD], 2007). Good schools with quality teachers providing healthy leaning environments and no corporal punishment can retain a higher volume of children in school.

Such schools provide a welcoming place to give proper guidance and care for children's all-round development. Keeping these issues in mind, the main focus of this research paper is to examine how the economic condition of any household determines the schooling pattern and over-age schooling among children aged 6-14 years in India. The wealth index has been used as background variables to determine the differentials of child schooling patterns in India. Although significant progress in school education in India has been realized, still we have a long way to go in achieving universal primary education with better retention rates. In this context this paper examines the economic differentials in school attendance using large-scale population based survey data in India.

\section{Research Questions}

The basic research question that we need to address is "Does poverty determine the schooling attendance pattern and over-age schooling in India?"

\section{Objectives}

The broad objective of this research paper is to understand the role of poverty for schooling patterns in India. The specific objectives are as follows:

1. To examine the linkages of poverty and school attendance (never attended, entered school, drop-out rates, school left 2 or more years ago and repeating in same class) in India.

2. To determine the child work status in India.

\section{Data and Methods}

The data for this paper are derived from National Family Health Survey (NFHS-3) conducted by the International Institute for Population Sciences (IIPS), Mumbai and ORC Macro International in 2005-06. It covers 99 percent of 
India's population from 29 states of India. NFHS-3 covers 1, 09,041 households and 5, 15,507 individuals enumerate throughout the country. Three types of questionnaires are used in NFHS-3 as (i) the Household questionnaire, (ii) the Women questionnaire, and (iii) the Men's questionnaire. The main domain of this data set covers a wide range of issues including fertility, mortality, family planning, HIV-related knowledge, nutrition, health and health care. In the household questionnaire about school activities, households were asked about children aged 6-14 years and the estimated percentage of schooling pattern in this research paper. The details of the survey findings and sampling procedure are available in national report (IIPS \& Macro International, 2007).

The information on educational attainment was covered in NFHS-3. The schooling attendance pattern is expressed in six categories ; (i) Never attended, (ii) Entered in school at proper age, (iii) Advanced in schooling, (iv) Repeating during schooling, (v) Dropout rate, and (vi) Left school 2 or more years ago. Differential in school attendance is examined by wealth status of the household.

The wealth index is used as one of the background variables to determine the differentials in child schooling pattern in this paper. The wealth index reflects the economic status of the household, constructed by using 33 household assets and housing characteristics such as household electrification, type of windows, drinking water source, type of toilet facility; material of exterior walls; type of roofing; cooking fuel; house ownership; number of household members per sleeping room; ownership of a bank or post-office account; and ownership of a mattress, a pressure cooker, a chair, a cot/bed, a table, an electric fan, a radio/transistor, a black and white television, a color television, a sewing machine, a mobile telephone, any other telephone, a computer, a refrigerator, a watch or clock, a bicycle, a motorcycle or scooter, an animal-drawn cart, a car, a water pump, a thresher, and a tractor (NFHS$3)$. This wealth quintile $(20 \%$ of household population in each group based on the score), derived from wealth index is used in the analyses. Bivariate analysis was used to determine the schooling attendance realities in India.

\section{Results}

In Table 1 the percentage of children aged 6-14 years school attendance status is explained. The school attendance status among all economic categories have clearly indicated that the bottom 20 percent households (poorest households) are more deprived in all aspects of school attendance in India. Among poorest households, children who never attended comprise 29.4 percent compared to 5.9 percent for the children of the richest households. This was a significant trend within all five 
Table 1. Percentage of Children Aged 6-14 Years School Attendance Status in India

\begin{tabular}{l|c|c|c|c|c|c}
\hline \multirow{2}{*}{ School attendance status } & \multicolumn{6}{c}{ Wealth index } \\
\cline { 2 - 8 } & Poorest & Poorer & Middle & Richer & Richest & Total \\
\hline Never attended & 29.4 & 19.1 & 13.2 & 8.8 & 5.9 & 15.5 \\
\hline Entered in school & 9.0 & 8.0 & 7.2 & 6.6 & 6.7 & 7.5 \\
\hline Advanced in school attendance & 52.1 & 64.0 & 72.2 & 79.1 & 83.9 & 69.9 \\
\hline Repeated in same class & 2.0 & 2.5 & 2.3 & 1.8 & 1.6 & 2.0 \\
\hline Dropout & 2.0 & 1.6 & 1.2 & 0.7 & 0.2 & 1.2 \\
\hline Left school 2+ years ago & 5.4 & 4.8 & 4.0 & 3.0 & 1.7 & 3.8 \\
\hline
\end{tabular}

economic categories of households. Other components of school attendance also followed the same trend with poorest household children more prone to never having attended, dropping out more frequently, repeating grades more often and less retention in schooling at both primary and secondary levels.

There are big differentials in schooling pattern between these two categories that have been persisted in India. The overall findings of this table concluded that poorer household children are more prone to never having attended, dropping out and leaving school due to economic hardship in the family. Apart from existing policies for school education in India, there is an urgent need to take measures to children who have never attended in particular states of India irrespective of poverty and regional disparities. Dropout rates among poor children are very high compared to wealthier children. This is also an important concern and challenge for us apart from various national schemes as Mid Day Meal, SSA, RMSA ad RTE are vehicles to achieve the universal primary education achievement in India. Gender differences in primary education enrollment also persist as girl children face more obstacles to continuing their higher education due to various socio-economic factors in India.

In the above table the percentage of school attendance pattern in India and its states have been presented. State wise, school attendance patterns have clearly indicated that among all 29 states the variations are too much in the direction of children never having attended, dropped out, repeated grades or left school two or more years ago. All these six components have been explained in Figures 1-6 as mentioned below.

In Figure 1, percentage of children aged 6-14 school attendance statuses in the states have explained. The findings clearly indicated that wide variations among all states have been found in terms of children never having attended. For example, Bihar is the highest with 39.4 percent never having attended compared to the lowest states of Kerala and Tamil Nadu where both have only 2 percent of children who have never 
attended. Household characteristics and the role of individual and school infrastructures are key determinants of child attendance in school in India (Dostie \& Jayaraman, 2006). The children from slum dwellers are not engaged in school due to families' bad circumstance and faulty school systems in urban settings (Banerji, 2000). The family size and number of children of households having illiterate mothers have an impact on child schooling as well (Bhat, 2002). Among poorest households, Meghalaya is the highest in children never having attended (70.4 percent, in table A) compared to other states' cohorts of poorest households. A number of states have more than 20 percent of children never having attended which is more than the national average of 16 percent.

Table 2. Percentage of Children Aged 6-14 School Attendance Status in India and it's States

\begin{tabular}{|c|c|c|c|c|c|c|}
\hline \multirow[b]{2}{*}{$\begin{array}{c}\text { Name of } \\
\text { states/UTs }\end{array}$} & \multicolumn{6}{|c|}{ Percentage of children aged 6-14 school attendance status } \\
\hline & $\begin{array}{l}\text { Never } \\
\text { attended }\end{array}$ & $\begin{array}{l}\text { Entered in } \\
\text { school }\end{array}$ & $\begin{array}{l}\text { Advanced } \\
\text { in term of } \\
\text { school } \\
\text { attendance }\end{array}$ & $\begin{array}{c}\text { Repeated } \\
\text { in same } \\
\text { class }\end{array}$ & Dropout & $\begin{array}{l}\text { School left } \\
2 \text { or more } \\
\text { years ago }\end{array}$ \\
\hline Andhra radesh & 10.1 & 3.5 & 76.8 & 1.0 & 2.2 & 6.4 \\
\hline Arunachal Pra. & 26.7 & 9.3 & 52.9 & 6.4 & 0.3 & 4.5 \\
\hline Assam & 7.9 & 5.1 & 76.4 & 3.0 & 1.5 & 6.1 \\
\hline Bihar & 39.4 & 9.9 & 47.7 & 0.3 & 0.7 & 2.1 \\
\hline Chhattisgarh & 13.8 & 10.8 & 65.0 & 4.3 & 2.0 & 4.2 \\
\hline Delhi & 10.2 & 7.4 & 77.2 & 1.0 & 0.4 & 3.9 \\
\hline Goa & 7.2 & 8.6 & 77.2 & 3.5 & 0.1 & 3.3 \\
\hline Gujarat & 7.8 & 3.2 & 75.7 & 5.9 & 1.6 & 5.8 \\
\hline Haryana & 12.6 & 6.6 & 74.1 & 1.8 & 0.6 & 4.3 \\
\hline Himachal Pra. & 3.9 & 2.8 & 90.8 & 1.2 & 0.4 & 0.9 \\
\hline Jharkhand & 25.2 & 12.1 & 53.9 & 1.3 & 0.4 & 7.1 \\
\hline $\mathrm{J} \& \mathrm{~K}$ & 12.5 & 7.6 & 73.4 & 1.6 & 0.4 & 4.5 \\
\hline Karnataka & 11.4 & 9.1 & 71.7 & 1.0 & 0.9 & 5.9 \\
\hline Kerala & 2.7 & 9.9 & 83.4 & 1.6 & 0.3 & 2.1 \\
\hline Madhya Pra. & 20.1 & 8.2 & 65.7 & 1.9 & 0.8 & 3.2 \\
\hline Maharashtra & 8.4 & 8.5 & 77.1 & 0.7 & 1.7 & 3.7 \\
\hline Manipur & 19.3 & 6.6 & 70.7 & 1.2 & 0.5 & 1.6 \\
\hline Meghalaya & 33.4 & 3.8 & 56.7 & 0.6 & 0.1 & 5.5 \\
\hline Mizoram & 9.7 & 5.6 & 81.3 & 0.1 & 0.6 & 2.6 \\
\hline Nagaland & 29.6 & 4.1 & 61.9 & 1.5 & 0.7 & 2.2 \\
\hline Odisha & 12.5 & 6.9 & 71.0 & 2.6 & 2.9 & 4.2 \\
\hline Punjab & 10.8 & 6.8 & 75.9 & 1.4 & 1.2 & 3.9 \\
\hline Rajasthan & 18.5 & 8.1 & 66.4 & 1.3 & 2.3 & 3.4 \\
\hline Sikkim & 20.7 & 12.7 & 57.7 & 5.6 & 0.3 & 3.1 \\
\hline Tamil Nadu & 2.7 & 8.3 & 85.2 & 0.7 & 0.4 & 2.7 \\
\hline Tripura & 10.8 & 8.1 & 72.2 & 5.7 & 0.9 & 2.4 \\
\hline Uttar Pradesh & 19.7 & 8.2 & 65.4 & 1.6 & 1.9 & 3.3 \\
\hline Uttaranchal & 6.3 & 2.0 & 81.0 & 7.3 & 0.3 & 3.0 \\
\hline West Bengal & 14.3 & 9.5 & 66.3 & 3.5 & 1.6 & 4.8 \\
\hline India & 15.5 & 7.5 & 69.9 & 2.0 & 1.2 & 3.8 \\
\hline
\end{tabular}


This needs serious attention from policy planners and government as to how to achieve one hundred percent enrollment and retain children in primary and secondary school education in India in the near future.

The percentage of children never having attended in particular states may be given more emphasis while others may see fit to adopt the existing policy on school education in India. Individual state have great role to enhance the primary education enrolments and retention particularly girls children from rural part of India.

Individual state have great role to enhance the primary education enrolments and retention particularly girls children from rural part of India.

In Figure 2 the percentage of children aged 6-14 who entered school in right age status in the states have presented. The findings regarding this right age at entry category are interesting in that states like Sikkim, Jharkhand, Chhattisgarh and Bihar have better proportions of children entering at the right age school compared to other States (Himachal and Uttaranchal). However, among poorest households of various States, Uttaranchal have the lowest attention towards proper age at school entry (1

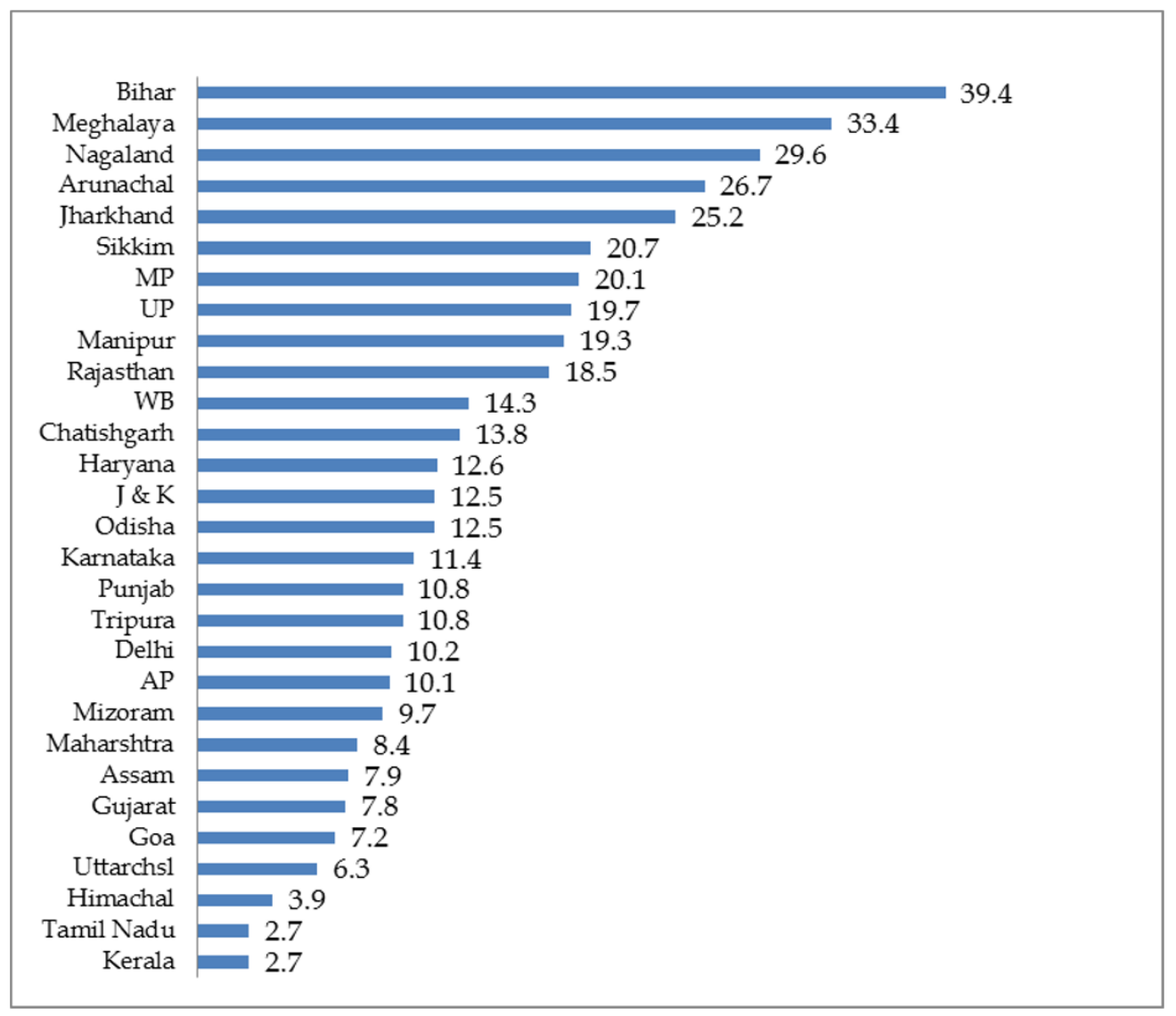

Figure 1. Percentage of children aged 6-14 school attendance as "Never attended status in India and its states" 
percent) compared to the wealthiest households of Sikkim (11.9 percent). The details of other economic groups of 29 states have been explained in Table B in the appendix section. The percentage of children aged 6-14 attending school in the states is explained in figure 3. States like Himachal Pradesh, Tamil Nadu, Mizoram and Kerala have better school attendance for the primary and secondary levels compared to lower performing states like Bihar, Arunachal and Jharkhand. Among poorest households from all states, Tamil Nadu has better advanced school attendance (81.6 percent) which compares favorably to the wealthiest households of Himachal which has 94.8 percent in advanced schooling. Household findings in every economic category have presented in Table C. In Figure 4 the percentage of children aged 6-14 attending school and repeating in the same class during schooling is presented for the states. This is a new category of information. The findings show that Uttaranchal is the highest, with 7.3 percent repeating in same class compared to the lowest, Mizoram, with 0.1 percent. One third of states have more than 3 percent of children repeating in the same class during their schooling. However,

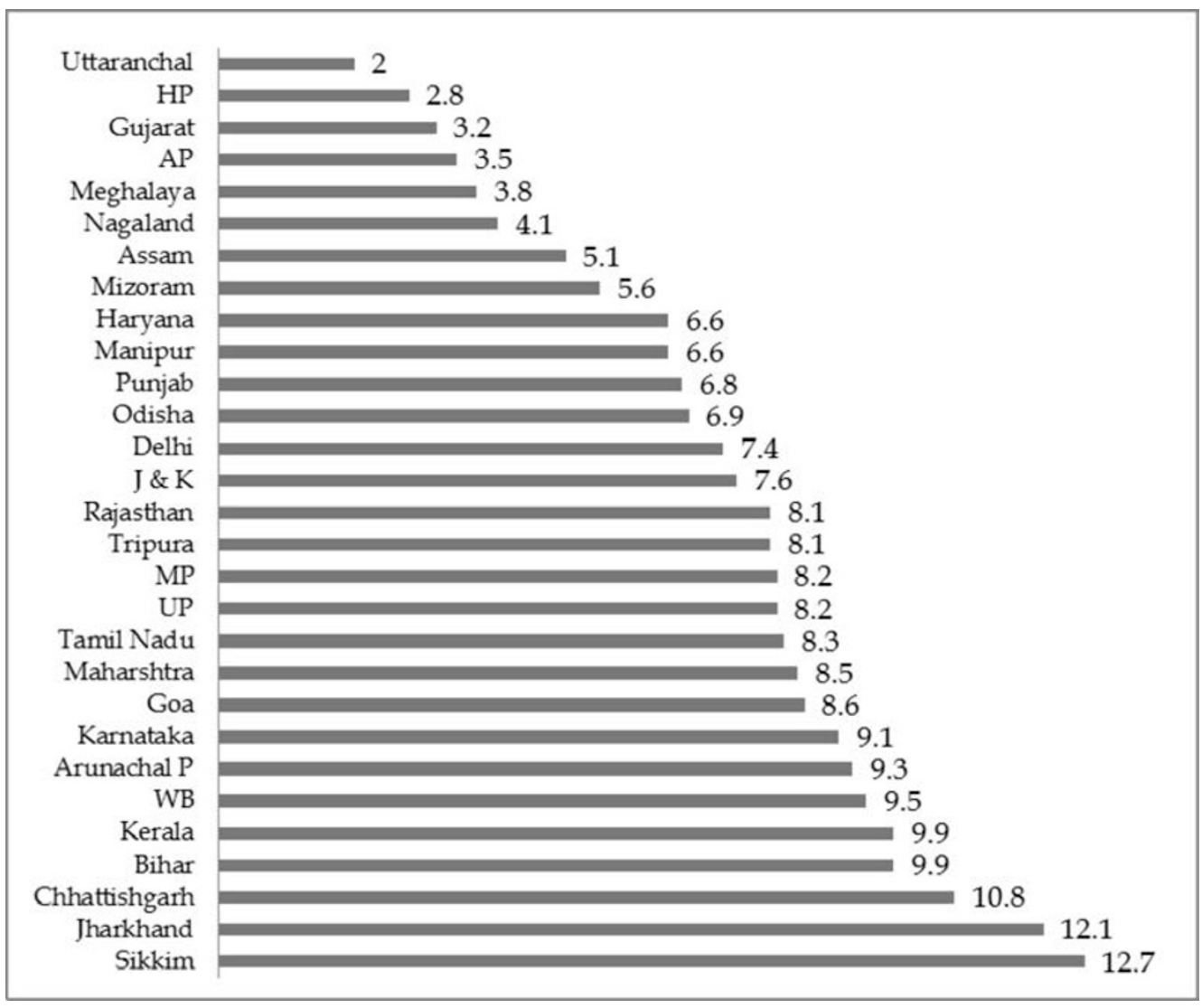

Figure 2. Percentage of children aged 6-14 "School attendance as entered school in proper age status in states of India" 
among poorest households among all states, Arunachal Pradesh has the highest (5.4\%) and among richest households, Uttaranchal is the highest $(8.2 \%)$ in class repeating. Other state findings are also explained detailed in Table -D. Reasons for repeating in same class may be desire on the part of parents for better improvement and higher expectations for children to score better marks in examination or, perhaps less importance placed by some parents on their children's schooling. The percentage of children aged 6-14 who attended school and dropped out in the states is presented in figure 5 . The dropout rate at primary level is considerably less compared to secondary and senior secondary levels in India. India is satisfactorily achieving its goals for overall enrollment for primary and secondary education. However, the retention rate at senior secondary levels is still poor compared to many countries. Girls are more prone to dropout at every level. Overall, primary education retention is only 71 percent and for girls it is only 47.79 percent (NUEPA, 2005-06). The household characteristics, namely parental schooling,

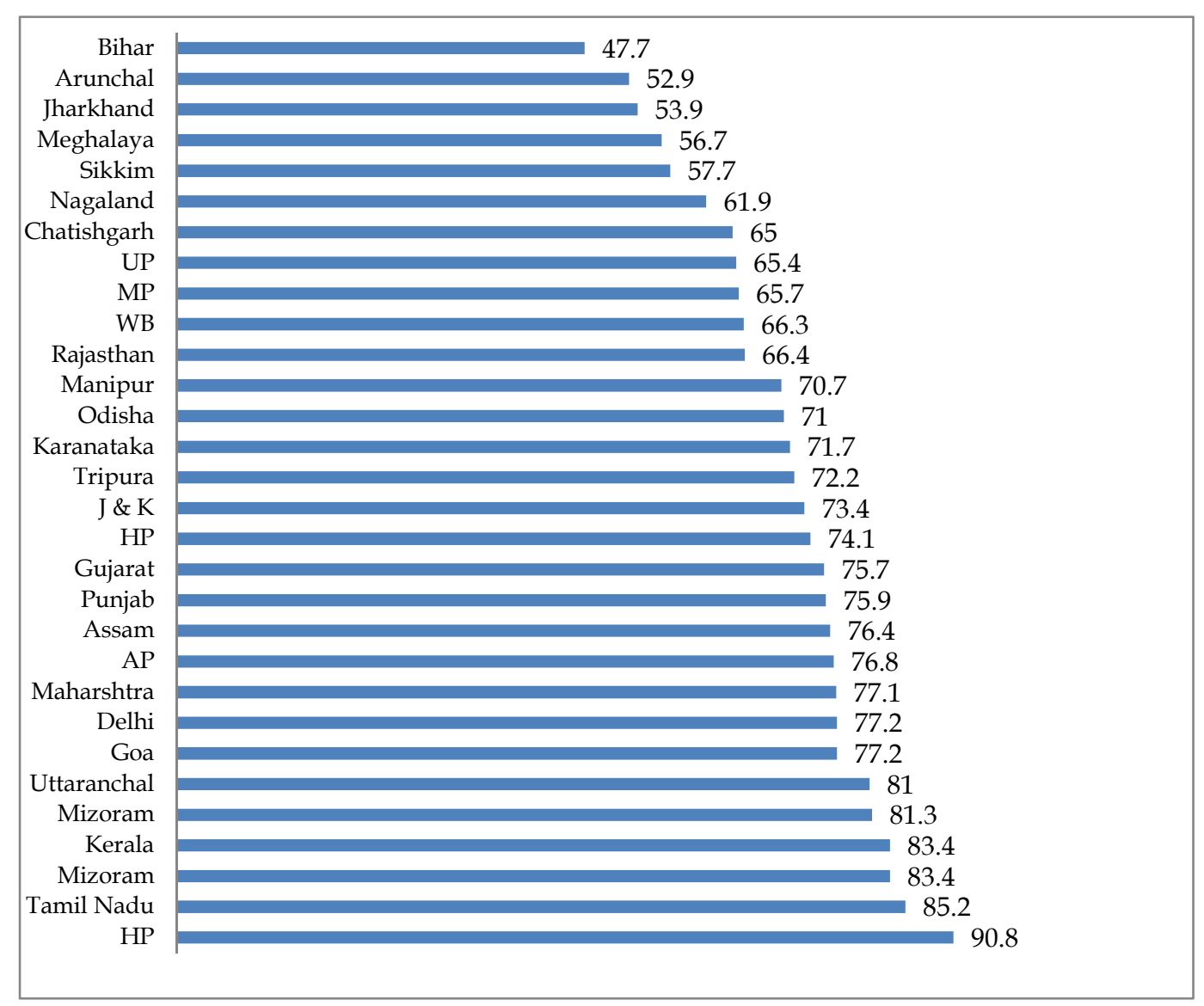

Figure 3. Percentage of children aged 6-14 "School attendance as advanced in school attendance status in states of India" 
especially maternal schooling, father's occupation, and family income are key determinants of girls schooling in a rural setting (Sengupta, 2002). School quality, parent's motivation and economic constraints of family level are obstacles to achieving better the school enrollment and reducing dropout rates (Bhatty, 2010). As the years of schooling increases the dropout level also increases at higher grade levels. Socioeconomic and demographic factors are playing an important role in dropping out of children in rural areas at various educational levels. Various research studies have stated that the distance of school from households, the existence of all-weather roads, school infrastructure and economic hardship in household are some of well-known factors for dropping out of children from school in India. This figure clearly indicates that Odisha has the highest dropout rate $(2.9 \%)$ compared to lowest $(0.1)$ at Meghalaya and Goa. States differentials vary more in total dropout rate. Among all poorest households, Himachal Pradesh has the highest $(8.8 \%)$ dropout rate and among wealthiest households Rajasthan has the highest (1.2\%) compared to any other wealthiest household children in Indian States.

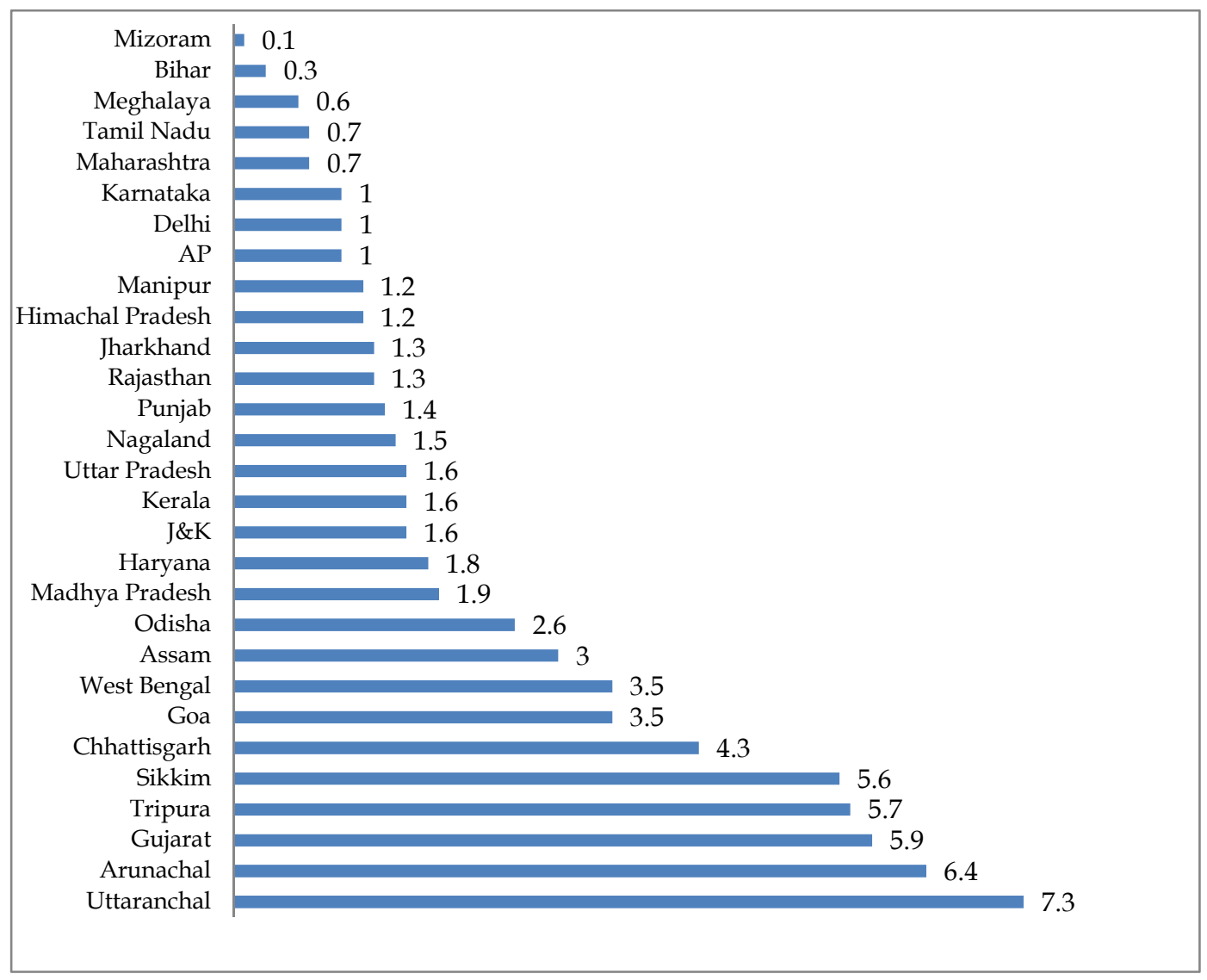

Figure 4. Percentage of children aged 6-14 school attendance as "Repeating in same class during schooling in states of India" 
Detailed economic sections household findings have elaborated in table -E. In Figure 6 the percentage of children aged 6-14 who attended school and left school 2 plus years before in the states is presented. Retention is a bigger problem than enrollment for all levels of school education. Every country supports its primary and secondary education achievement from a long-run development perspective. All developed countries have a remarkable achievement in all levels of school education. Developing countries are confronting and reducing the dropout rate and increasing enrollment through various national programmes. In India, programmes like Sarva Sikhya Abhiyan (SSA), Rastryia Madhyamic Shikshya Abhiyan (RMSA), Right to Education (RTE), and various NGOs (Pratham and others) are also working toward enrolling all children aged 6-14 years and taking steps to retain the huge child population in school for a longer duration. In above figure Jharkhand state children leaving school two or more years ago is the highest (7.1 percent) compared to lowest (0.9 percent) at Himachal Pradesh. Among poorest households among all States,

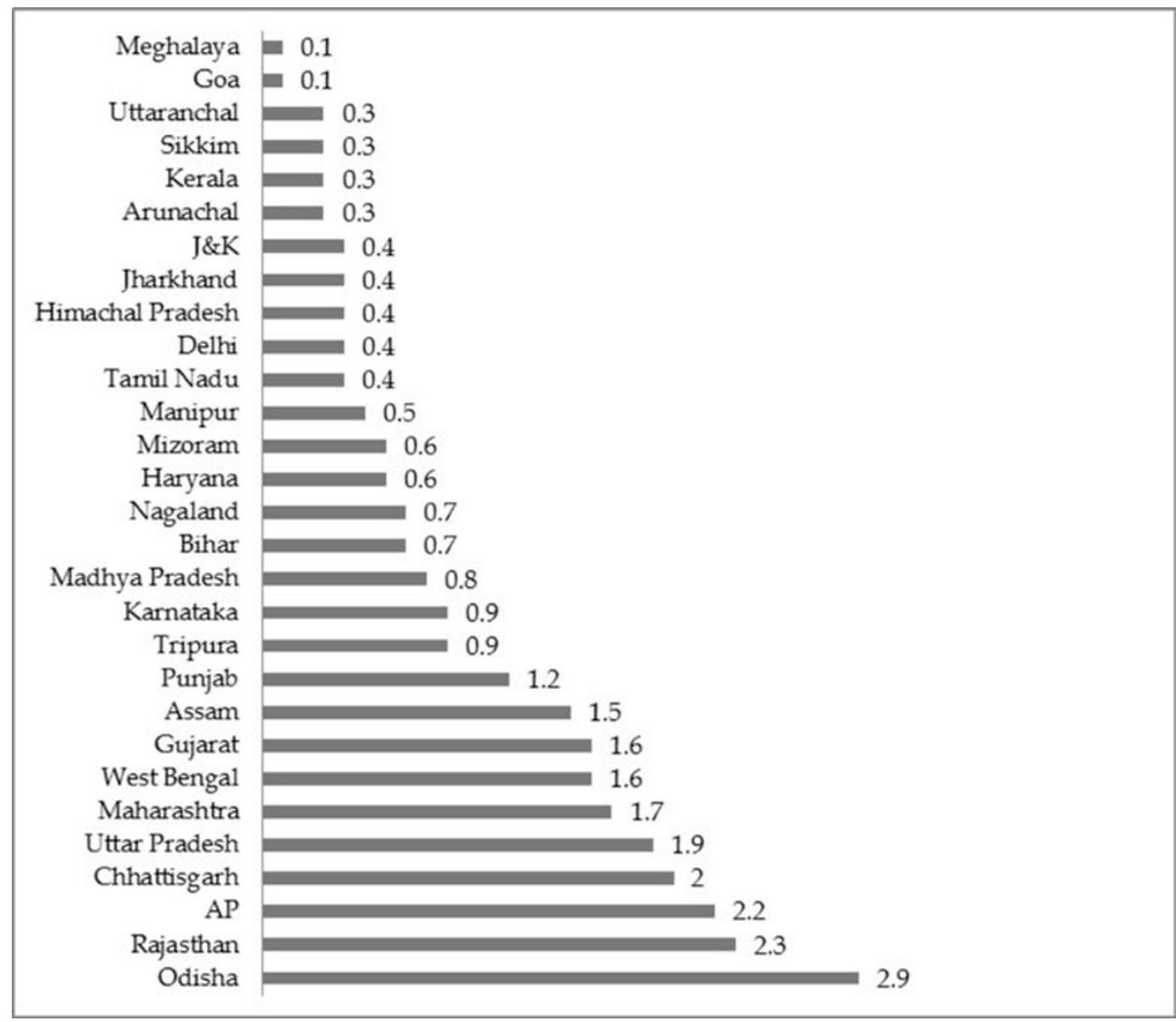

Figure 5. Percentage of children aged 6-14 school attendance as "School dropout status in states"

Source: Author's calculation from NFHS-3 
Andhra Pradesh's poorest-household children are leaving school two or more years ago at the highest rate (11.5 percent) and among the wealthiest households, Arunachal Pradesh's wealthiest households are highest among all states in leaving schools two or more years ago. Detailed findings for all states have been presented in table $\mathrm{F}$.

In Figure 7 the percent of children aged 5-14 years who are working is presented. It is found that Gujarat has the highest proportion of child workers compared to the lowest which are Goa and Kerala. This is so even though
Gujarat is economically developed. States of India with larger child working populations in do so because of economic opportunity in those states are high compared other states of India. Other probable reasons for high child worker populations may be due to high number of families with family businesses. In such cases, parents find it advantageous to have their own children engaged in their farms or business activities. It clearly indicates that school attendance rate is very high in states with lower percentage of working children (Figure 1).

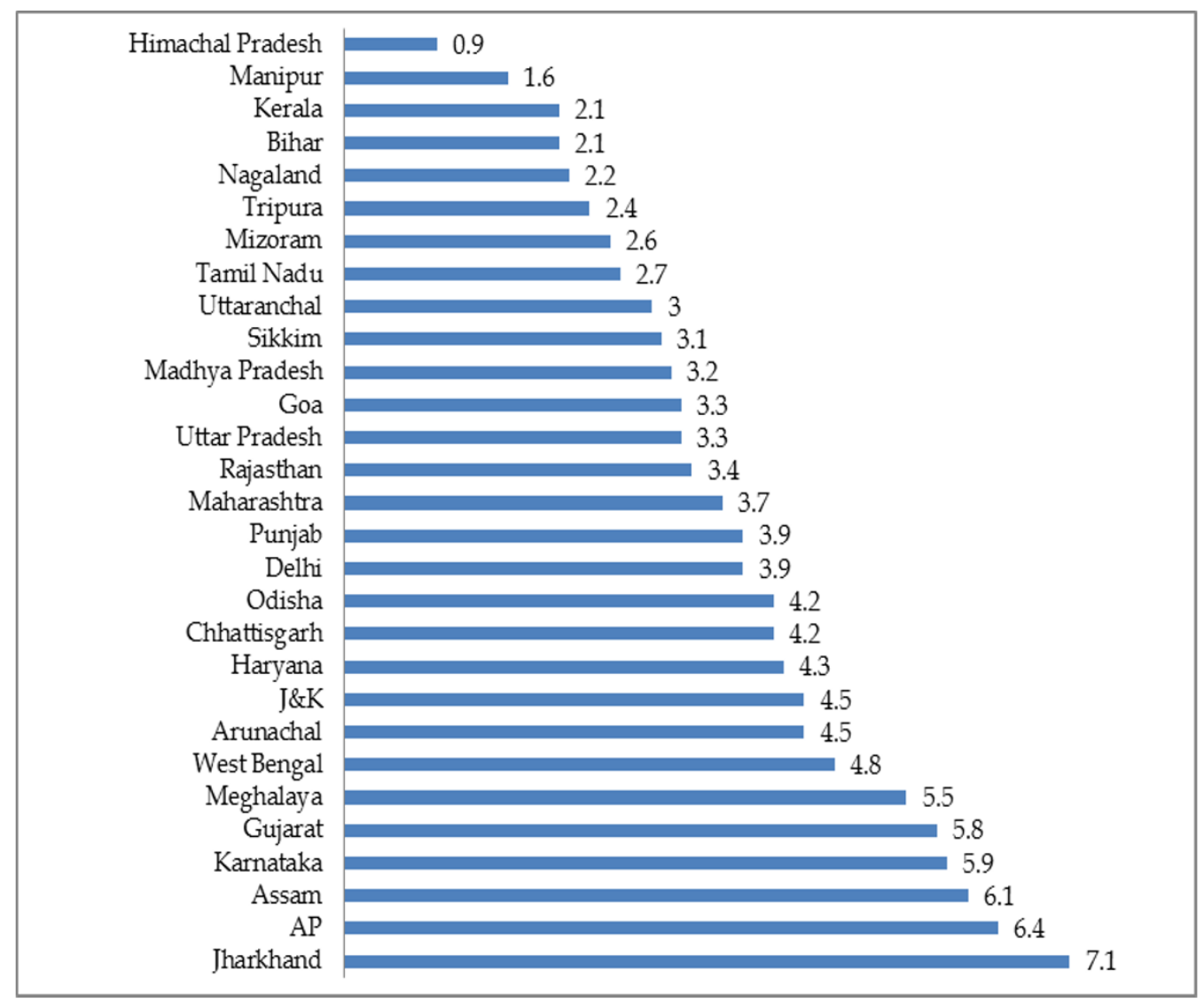

Figure 6. Percentage of children aged 6-14 school attendance "Left school 2+ years before in States"

Source: Author's calculation from NFHS-3 


\section{Conclusion}

The broad objective of this research paper is to understand the role of poverty in schooling attendance patterns in India. The parameters for measurement consists of six components: never attended, dropped out, entered in school at proper age, advanced in school attendance, repeated in same class during schooling and left school two or more years ago. These are analyzed with various economic segments: poorest, poor, middle, wealthy and wealthiest based on wealth quintiles for the purpose of determining the status of child schooling patterns in India. For never attended children in primary schools, Bihar is the highest total compared to the lowest neverattended states of Kerala and Tamil Nadu. An important finding of this study suggests that in all economically poor states, children schooling patterns such as dropout rate, repetition in same class, left school two or more years ago and advanced attendance are very high compared to the children belonging to the better socio-economic states. From a policy point of view states like Bihar, Odisha, Jharkhand, Chhattisgarh, and

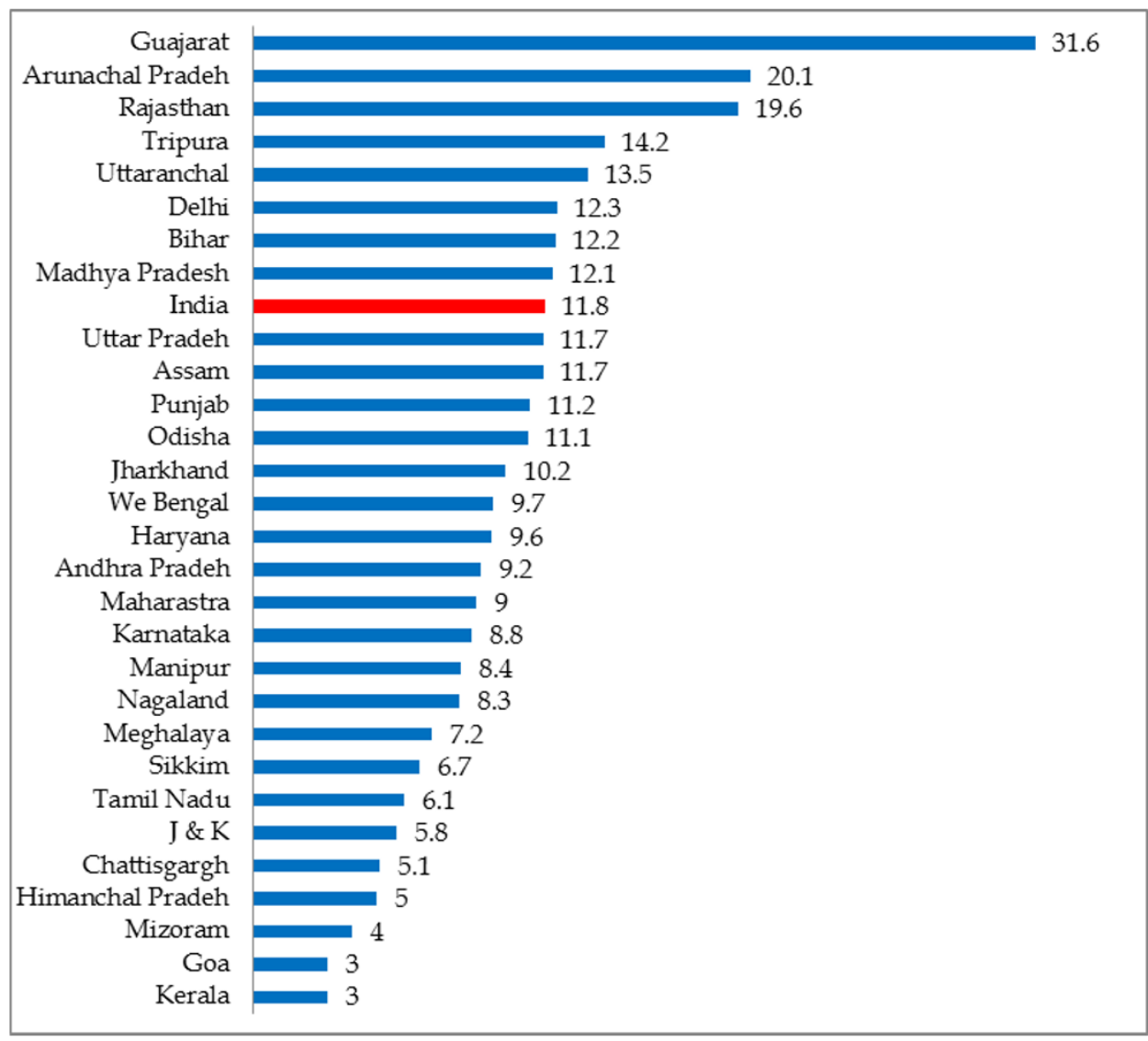

Figure 7. Percent of 5-14 years children engaged in work in India Source: Author's calculation from NFHS-3 
Rajasthan need special attention aimed at attaining better achievement of the overall schooling enrollment, retentions, reduction of dropout rate and over-age enrollment specifically. Poorest household's children in India need immediate attention focused on these issues related to school education at primary and secondary levels, irrespective of class, caste and religions. Various children-friendly school education programmes may be promoted in these marginalized groups for reducing negative aspects of school education, particularly in rural areas. States having more working children are also more likely to have children who never attended school. Although Gujarat is a better socioeconomic state among all other States of India, the working child is most numerous in this State. This may be due to the urban economic opportunities available for children in this State. Retention of children in school for a longer duration to complete the school education is a big challenge for us in the current scenario.

\section{References}

Banerji, R. (2000). Poverty and Primary Schooling: Field Studies from Mumbai and Delhi, Economic and Political Weekly, 35(10) 795-802

Benjamin, L. (2007). Educational responses to poverty. Canadian Journal of Education, 20:2, September 10, 2007 Canada.

Bhat, P. N. (2002). Demographic Transition, Family Size and Child Schooling. National Council of Applied Economic
Research, (86), 1-20.

Bhatty, K. (2010). Educational Deprivation in India: A Survey of Field Investigations, Economic and Political Weekly, 33(27), 1731-1740

Brooks-Gunn, J., \& Duncan, G. J. (1997). The effects of poverty on children. The Future of Children, Summer/ Fall, 1997. CO: Princeton University.

Chaudhuri, D. P., \& R. Jha, R.. (2011). Child Poverty and Compulsory Elementary Education in India: policy insights from household data analysis, Working Paper No. 04. Australia South Asia Research Centre.

Dostie, B., \& Jayaraman, R. (2006). Determinants of School Enrolment in Indian Villages, Economic Development and Cultural Change, 54(2), 405-421

Duncan, G. J., Brooks-Gunn, J., \& Klebanov, P. K. (1994). Economic deprivation and early childhood development, Child Development. 1994 Apr; 65 (2 Spec No): 296-318.

Edmonds, V. E., Pavcnik, N., \& Topalova, P. (2008). Child labour and schooling in a globalizing world: Some evidence from urban India. Child Development, 1994, April. 65 (2 Spec No): 296-318. Department of Economics Dartmouth College, NBER and IZA.

Engle, P. L., \& Black, M. M. (2008). The effect of poverty on child development and educational outcomes. CA: California Polytechnic State University.

Ferguson, H. B., Bovaird, S. \& Muller, M. P. (2007). The impact of poverty on educational outcomes for children, Paediatric Child Health. 2007 October; 12(8): 701-706. 
Filmer, D., \& Pritchett, L. (1999). Educational enrolment and attainment in India: Household wealth, gender, village and state effects. Journal of Educational Planning and Administration, 13: 135-163.

Hazarika, G., \& Arjun S. BediB. (2006). Child work and schooling cost in Rural Northern India. Discussion paper series, IZA DP No-2136.

Horgan, G. (2007). Impact of poverty on young children's experience of school, Joseph Rowntree Foundation, U.K.

International Institute for Population Sciences (IIIS) and Macro International. (2007). National Family Health Survey (NFHS-3), 2005-06: India, Mumbai, IIPS.

Ladd, H. F., \& Fiske, E. B. (2011). Class Matters. Why Won't We Admit It? The New York Times, USA.

Leventhal, T., Fauth, R.C., \& Brooks-Gunn, J. (2005). Neighbourhood poverty and public policy: a 5-year follow-up of children's educational outcomes in the New York City moving to opportunity demonstration, Development Psychology 41: 933-952.

Levin, B. (2007). Schools, poverty, and the achievement gap. Phi Delta Kappa, 89(1), 75-76.

Malik, B, \& Mohanty, S. (2009). Rural Poverty and Schooling: A Case Study of Balasore District of Rural Orissa. Journal of Educational Planning and Administration (NUEPA). Jul-Sep, 2009, Vol. No-XXIII, No-3, pp-257-281, New Delhi.

Ministry of Women and Child Development Government of India. (2007). A study on child abuse in India. New Delhi.
Minitry of Human Resource Development. (1968, 1986, 1992). National Policy of Education.

Minitry of Human Resource Development. (2009). Website: http://www.education.nic. in/for details on the 2009 Act.

Montgomery, M., Kouame, A., \& Oliver, R. (1995). The trade off between number of children and child schooling: evidence from Cote d'Ivoire and Ghana. World Bank Working Paper. No. 112. Washington D.C.: World Bank.

Murnane, R. J. (2007). Improving the education of children living in poverty. Future Child 17: 161-182.

National University of Educatonal Planning and Administraton (NUEPA). (2005). Elementary Education in India Progress towards UEE: Flash Statistics DISE 200506. New Delhi.

Office of the Registrar General and Census Commissioner, India. (2001). Primary census Abstract, India, Series -1. Census of India, Primary census Abstract, India, Series -1. New Delhi.

Office of the Registrar General and Census Commissioner, India. (2011). Provisional Data. Census of India, Provisional Data. New Delhi.

Rajaram, S., \& Jayachadran. V. (2007). Child labour and schooling outcomes among children in India: An analysis of levels, trends and differentials. PAA, session 154, New York.

Ridge, T. (2002). Childhood Poverty and Social Exclusion: the child's perspective, Policy press, Bristol.

Sample Registration Systems. (2010). Statistical report 2010, Office of the Registrar General, India Ministry of 
Home Affairs, Govt. of India, New Delhi.

Save the Cchildren. (2012). Save the Children Report.

Website http://www.savethechildrenindia.

org

Sengupta, P., \& Guha, J. (2002). Enrolment, drop out and grade completion of girl children in west Bengal, Economic and Political Weekly, 37(17), 1621-1637.

The United Nations Children's Fund [UNICEF]. (2012). Progress for Children:

A Report card on Adolescents. Number 10, April 2012.

Times of India. (20/9/2012). New Delhi Edition.

Times of India. (2012). Poverty, poor schools pushing kids to child labour, 30 September, 2012, Madurai Edition, India.

\section{Notes}

Work includes children age 5-11 years who in the 7 days preceding the survey, worked for someone who is not a member of the household, with or without pay, or did household chores for 28 or more hours or engaged in any other family work and children age 12-14 years who in the 7 days preceding the survey, worked for someone who is not a member of the household, with or without pay, for 14 or more hours or did household chores for 28 or more hours or engaged in any other family work for 14 or more hours. 


\section{Appendix}

Table A. School Attendance as "Never Attended" Linked with Poverty Status by State

\begin{tabular}{l|c|c|c|c|c|c}
\hline \multirow{2}{*}{ Name of states/UTs } & \multicolumn{5}{|c}{ Wealth index } & \\
\cline { 2 - 7 } & Poorest & Poorer & Middle & Richer & Richest & Total \\
\hline Andhra Pradesh & 20.5 & 13.2 & 8.5 & 7.2 & 5.4 & 10.1 \\
\hline Arunachal Pradesh & 43.2 & 32.8 & 19.6 & 12.4 & 18.0 & 26.7 \\
\hline Assam & 15.4 & 4.3 & 7.4 & 3.7 & 5.4 & 7.9 \\
\hline Bihar & 57.8 & 43.1 & 27.1 & 18.8 & 13.9 & 39.4 \\
\hline Chhattisgarh & 21.5 & 8.3 & 8.5 & 6.4 & 5.0 & 13.8 \\
\hline Delhi & 50.0 & 47.9 & 24.0 & 13.9 & 4.5 & 10.2 \\
\hline Goa & 23.1 & 13.9 & 7.9 & 8.3 & 4.6 & 7.2 \\
\hline Gujarat & 32.4 & 12.2 & 6.2 & 3.6 & 1.5 & 7.8 \\
\hline Haryana & 36.5 & 21.2 & 15.6 & 7.0 & 3.9 & 12.6 \\
\hline Himachal Pradesh & 14.7 & 7.7 & 3.5 & 2.6 & 3.6 & 3.9 \\
\hline Jharkhand & 33.3 & 18.3 & 18.0 & 11.2 & 13.6 & 25.2 \\
\hline J\& K & 33.7 & 19.3 & 11.8 & 10.4 & 7.7 & 12.5 \\
\hline Karnataka & 25.9 & 13.8 & 9.3 & 6.5 & 4.7 & 11.4 \\
\hline Kerala & 9.1 & 5.6 & 3.2 & 1.5 & 3.2 & 2.7 \\
\hline Madhya Pradesh & 31.0 & 16.7 & 11.0 & 6.7 & 7.4 & 20.1 \\
\hline Maharashtra & 23.2 & 11.6 & 6.8 & 4.3 & 3.3 & 8.4 \\
\hline Manipur & 36.5 & 34.2 & 18.8 & 13.1 & 6.3 & 19.3 \\
\hline Meghalaya & 70.4 & 48.7 & 32.3 & 15.9 & 5.3 & 33.4 \\
\hline Mizoram & 37.2 & 20.8 & 11.3 & 8.0 & 5.2 & 9.7 \\
\hline Nagaland & 62.8 & 44.4 & 26.4 & 16.7 & 16.7 & 29.6 \\
\hline Odisha & 22.0 & 8.0 & 4.2 & 1.1 & 0.7 & 12.5 \\
\hline Punjab & 49.1 & 24.2 & 17.0 & 7.4 & 5.6 & 10.8 \\
\hline Rajasthan & 34.1 & 19.2 & 14.7 & 8.2 & 3.9 & 18.5 \\
\hline Sikkim & 34.1 & 26.6 & 24.5 & 16.0 & 17.4 & 20.7 \\
\hline Tamil Nadu & 5.0 & 3.6 & 2.2 & 1.7 & 2.4 & 2.7 \\
\hline Tripura & 30.3 & 11.2 & 6.2 & 5.8 & 1.7 & 10.8 \\
\hline Uttar Pradesh & 26.6 & 20.2 & 16.2 & 16.2 & 9.5 & 19.7 \\
\hline Uttaranchal & 13.9 & 11.9 & 8.6 & 2.5 & 1.7 & 6.3 \\
\hline West Bengal & 22.9 & 12.9 & 10.8 & 7.2 & 7.1 & 14.3 \\
\hline India & $\mathbf{2 9 . 4}$ & $\mathbf{1 9 . 1}$ & $\mathbf{1 3 . 2}$ & $\mathbf{8 . 8}$ & 5.9 & $\mathbf{1 5 . 5}$ \\
\hline & & & & & & \\
\hline
\end{tabular}

Table B. School Attendance as "Entered School" Linked with Poverty Status by State

\begin{tabular}{l|c|c|c|c|c|c}
\hline \multirow{2}{*}{ Name of states/UTs } & \multicolumn{5}{|c}{ Wealth index } & \\
\cline { 2 - 7 } & Poorest & Poorer & Middle & Richer & Richest & Total \\
\hline Andhra Pradesh & 1.7 & 4.4 & 3.8 & 3.7 & 2.6 & 3.5 \\
\hline Arunachal Pradesh & 10.0 & 13.0 & 8.2 & 6.7 & 6.8 & 9.3 \\
\hline Assam & 8.3 & 5.0 & 3.5 & 2.3 & 3.4 & 5.1 \\
\hline Bihar & 9.1 & 11.4 & 10.0 & 10.2 & 6.5 & 9.9 \\
\hline Chhattisgarh & 11.6 & 11.9 & 9.6 & 9.1 & 7.1 & 10.8 \\
\hline Delhi & 16.7 & 4.2 & 8.7 & 9.9 & 6.3 & 7.4 \\
\hline Goa & 9.2 & 8.0 & 8.5 & 9.5 & 8.2 & 8.6 \\
\hline Gujarat & 6.2 & 4.3 & 4.2 & 1.9 & 2.0 & 3.2 \\
\hline Haryana & 6.6 & 7.2 & 4.4 & 7.3 & 7.9 & 6.6 \\
\hline Himachal Pradesh & 0.0 & 4.6 & 3.3 & 3.5 & 1.2 & 2.8 \\
\hline
\end{tabular}




\begin{tabular}{l|c|c|c|c|c|c}
\hline Jharkhand & 12.3 & 13.5 & 11.2 & 11.9 & 9.3 & 12.1 \\
\hline J \& K & 6.5 & 9.0 & 7.8 & 5.2 & 9.7 & 7.6 \\
\hline Karnataka & 7.6 & 8.6 & 9.1 & 9.6 & 10.5 & 9.1 \\
\hline Kerala & 15.2 & 10.1 & 12.0 & 10.0 & 9.1 & 9.9 \\
\hline Madhya Pradesh & 8.9 & 7.5 & 9.1 & 7.1 & 7.4 & 8.2 \\
\hline Maharashtra & 8.2 & 8.2 & 8.9 & 7.8 & 9.1 & 8.5 \\
\hline Manipur & 11.1 & 7.8 & 6.4 & 5.8 & 6.1 & 6.6 \\
\hline Meghalaya & 2.9 & 3.1 & 4.1 & 3.6 & 5.0 & 3.8 \\
\hline Mizoram & 14.0 & 6.7 & 4.1 & 6.3 & 5.2 & 5.6 \\
\hline Nagaland & 4.9 & 5.3 & 4.5 & 3.0 & 2.9 & 4.1 \\
\hline Odisha & 8.8 & 5.5 & 5.2 & 4.2 & 6.2 & 6.9 \\
\hline Punjab & 8.8 & 8.7 & 6.7 & 6.5 & 6.6 & 6.8 \\
\hline Rajasthan & 9.9 & 6.7 & 8.5 & 6.7 & 7.4 & 8.1 \\
\hline Sikkim & 22.0 & 18.1 & 12.0 & 10.6 & 11.9 & 12.7 \\
\hline Tamil Nadu & 6.8 & 9.0 & 8.2 & 8.4 & 8.8 & 8.3 \\
\hline Tripura & 11.4 & 8.4 & 7.9 & 4.1 & 8.5 & 8.1 \\
\hline Uttar Pradesh & 8.4 & 8.8 & 9.1 & 7.0 & 6.2 & 8.2 \\
\hline Uttaranchal & 1.0 & 1.6 & 3.2 & 2.1 & 1.4 & 2.0 \\
\hline West Bengal & 11.8 & 8.8 & 8.3 & 7.6 & 9.2 & 9.5 \\
\hline India & $\mathbf{9 . 0}$ & $\mathbf{8 . 0}$ & $\mathbf{7 . 2}$ & $\mathbf{6 . 6}$ & $\mathbf{6 . 7}$ & $\mathbf{7 . 5}$ \\
\hline
\end{tabular}

Table C. School Attendance as "Advanced" Linked with Poverty Status by States

\begin{tabular}{l|c|c|c|c|c|c}
\hline \multirow{2}{*}{ Name of states/UTs } & \multicolumn{5}{|c|}{ Wealth index } & \\
\cline { 2 - 7 } & Poorest & Poorer & Middle & Richer & Richest & Total \\
\hline Andhra Pradesh & 62.6 & 68.7 & 76.3 & 83.4 & 90.4 & 76.8 \\
\hline Arunachal Pradesh & 34.3 & 43.5 & 59.7 & 68.9 & 68.0 & 52.9 \\
\hline Assam & 62.6 & 78.6 & 79.7 & 88.1 & 85.7 & 76.4 \\
\hline Bihar & 29.6 & 42.5 & 59.8 & 68.2 & 78.6 & 47.7 \\
\hline Chhattisgarh & 53.4 & 68.6 & 74.7 & 80.4 & 85.1 & 65.0 \\
\hline Delhi & 33.3 & 36.6 & 57.7 & 65.9 & 86.9 & 77.2 \\
\hline Goa & 52.3 & 70.8 & 72.9 & 73.9 & 82.6 & 77.2 \\
\hline Gujarat & 46.2 & 66.7 & 71.6 & 82.1 & 89.2 & 75.7 \\
\hline Haryana & 48.5 & 59.2 & 72.6 & 80.1 & 85.0 & 74.1 \\
\hline Himachal Pradesh & 76.5 & 80.7 & 89.8 & 93.2 & 94.0 & 90.8 \\
\hline Jharkhand & 44.7 & 57.9 & 65.1 & 69.1 & 71.7 & 53.9 \\
\hline J \& K & 53.3 & 64.5 & 73.2 & 78.4 & 77.5 & 73.4 \\
\hline Karnataka & 53.5 & 67.7 & 74.8 & 78.1 & 81.1 & 71.7 \\
\hline Kerala & 66.7 & 76.4 & 79.5 & 85.8 & 83.7 & 83.4 \\
\hline Madhya Pradesh & 54.5 & 68.5 & 72.8 & 80.0 & 82.8 & 65.7 \\
\hline Maharashtra & 57.1 & 71.0 & 77.2 & 84.1 & 85.2 & 77.1 \\
\hline Manipur & 44.4 & 52.7 & 71.7 & 78.9 & 85.1 & 70.7 \\
\hline Meghalaya & 20.6 & 42.3 & 55.8 & 74.5 & 86.3 & 56.7 \\
\hline Mizoram & 39.5 & 64.2 & 79.9 & 83.2 & 88.3 & 81.3 \\
\hline Nagaland & 27.7 & 44.5 & 65.2 & 76.4 & 76.5 & 61.9 \\
\hline Odisha & 56.5 & 76.6 & 83.3 & 90.4 & 89.5 & 71.0 \\
\hline Punjab & 35.1 & 54.9 & 66.7 & 79.9 & 83.9 & 75.9 \\
\hline Rajasthan & 48.1 & 66.1 & 68.3 & 79.8 & 85.5 & 66.4 \\
\hline Sikkim & 34.1 & 38.6 & 53.1 & 66.9 & 64.8 & 57.7 \\
\hline Tamil Nadu & 81.6 & 83.4 & 85.9 & 85.8 & 87.7 & 85.2 \\
\hline Tripura & 47.0 & 69.5 & 77.0 & 86.5 & 84.7 & 72.2 \\
\hline & & & & & & \\
\hline
\end{tabular}




\begin{tabular}{l|l|l|l|l|l|l}
\hline Uttar Pradesh & 57.0 & 63.5 & 67.5 & 71.7 & 82.2 & 65.4 \\
\hline Uttaranchal & 73.1 & 77.1 & 77.6 & 83.0 & 87.3 & 81.0 \\
\hline West Bengal & 53.0 & 65.7 & 74.2 & 78.0 & 80.2 & 66.3 \\
\hline India & $\mathbf{5 2 . 1}$ & $\mathbf{6 4 . 0}$ & $\mathbf{7 2 . 2}$ & $\mathbf{7 9 . 1}$ & $\mathbf{8 3 . 9}$ & $\mathbf{6 9 . 9}$ \\
\hline
\end{tabular}

Table D. School Attendance as "Repeating" Linked with Poverty Status by States

\begin{tabular}{l|c|c|c|c|c|c}
\hline \multirow{2}{*}{ Name of states/UTs } & \multicolumn{5}{|c}{ Wealth index } & Richest \\
\cline { 2 - 7 } & Poorest & Poorer & Middle & Richer & Total \\
\hline Andhra Pradesh & 0.8 & 0.8 & 1.5 & 0.7 & 0.9 & 1.0 \\
\hline Arunachal Pradesh & 5.4 & 6.2 & 9.4 & 7.7 & 2.9 & 6.4 \\
\hline Assam & 3.4 & 3.7 & 2.6 & 1.9 & 1.7 & 3.0 \\
\hline Bihar & 0.4 & 0.2 & 0.4 & 0.0 & 0.0 & 0.3 \\
\hline Chhattisgarh & 4.5 & 5.1 & 4.1 & 2.3 & 2.5 & 4.3 \\
\hline Delhi & 0.0 & 1.4 & 1.3 & 1.2 & 0.8 & 1.0 \\
\hline Goa & 4.6 & 2.2 & 5.2 & 4.6 & 2.5 & 3.5 \\
\hline Gujarat & 5.8 & 6.8 & 7.4 & 5.2 & 4.7 & 5.9 \\
\hline Haryana & 2.4 & 2.6 & 1.9 & 1.1 & 1.8 & 1.8 \\
\hline Himachal Pradesh & 0.0 & 1.8 & 1.8 & 0.7 & 0.9 & 1.2 \\
\hline Jharkhand & 1.6 & 1.4 & 1.2 & 0.5 & 0.8 & 1.3 \\
\hline J \& K & 2.2 & 1.1 & 2.1 & 2.2 & 0.4 & 1.6 \\
\hline Karnataka & 0.6 & 0.5 & 1.5 & 1.0 & 1.2 & 1.0 \\
\hline Kerala & 3.0 & 2.2 & 1.8 & 1.5 & 1.5 & 1.6 \\
\hline Madhya Pradesh & 1.7 & 2.2 & 2.6 & 1.7 & 1.6 & 1.9 \\
\hline Maharashtra & 0.3 & 1.1 & 0.8 & 0.6 & 0.5 & 0.7 \\
\hline Manipur & 0.0 & 1.5 & 1.1 & 1.1 & 1.5 & 1.2 \\
\hline Meghalaya & 0.0 & 1.0 & 0.7 & 0.4 & 0.3 & 0.6 \\
\hline Mizoram & 0.0 & 0.8 & 0.0 & 0.0 & 0.0 & 0.1 \\
\hline Nagaland & 0.8 & 1.7 & 1.4 & 1.6 & 1.7 & 1.5 \\
\hline Odisha & 3.0 & 2.5 & 1.7 & 2.0 & 2.9 & 2.6 \\
\hline Punjab & 1.8 & 1.8 & 1.7 & 1.4 & 1.1 & 1.4 \\
\hline Rajasthan & 0.9 & 1.4 & 2.0 & 1.5 & 0.5 & 1.3 \\
\hline Sikkim & 7.3 & 13.1 & 6.0 & 4.5 & 2.2 & 5.6 \\
\hline Tamil Nadu & 0.8 & 0.6 & 0.5 & 1.1 & 0.6 & 0.7 \\
\hline Tripura & 4.9 & 8.9 & 5.2 & 2.3 & 1.7 & 5.7 \\
\hline Uttar Pradesh & 1.3 & 2.0 & 1.8 & 1.3 & 1.1 & 1.6 \\
\hline Uttaranchal & 5.0 & 4.8 & 8.4 & 8.0 & 8.2 & 7.3 \\
\hline West Bengal & 3.8 & 5.0 & 2.2 & 2.9 & 1.3 & 3.5 \\
\hline India & $\mathbf{2 . 0}$ & $\mathbf{2 . 5}$ & $\mathbf{2 . 3}$ & $\mathbf{1 . 8}$ & $\mathbf{1 . 6}$ & $\mathbf{2 . 0}$ \\
\hline & & & & & & \\
\hline
\end{tabular}

Table E. School Attendance as "Drop out" Linked with Poverty Status by States

\begin{tabular}{l|c|c|c|c|c|c}
\hline \multirow{2}{*}{ Name of states/UTs } & \multicolumn{5}{|c|}{ Wealth index } & \\
\cline { 2 - 7 } & Poorest & Poorer & Middle & Richer & Richest & Total \\
\hline Andhra Pradesh & 2.9 & 4.3 & 2.1 & 1.6 & 0.0 & 2.2 \\
\hline Arunachal Pradesh & 0.0 & 0.9 & 0.0 & 0.0 & 0.4 & 0.3 \\
\hline Assam & 2.4 & 1.7 & 1.2 & 0.9 & 0.0 & 1.5 \\
\hline Bihar & 1.0 & 0.8 & 0.6 & 0.2 & 0.0 & 0.7 \\
\hline Chhattisgarh & 2.9 & 1.8 & 1.1 & 1.1 & 0.0 & 2.0 \\
\hline Delhi & 0.0 & 0.0 & 1.0 & 0.9 & 0.2 & 0.4 \\
\hline
\end{tabular}




\begin{tabular}{l|l|l|l|l|l|l}
\hline Goa & 1.5 & 0.0 & 0.0 & 0.4 & 0.0 & 0.1 \\
\hline Gujarat & 3.3 & 1.9 & 2.3 & 1.4 & 0.5 & 1.6 \\
\hline Haryana & 1.2 & 1.4 & 0.6 & 0.6 & 0.0 & 0.6 \\
\hline Himachal Pradesh & 8.8 & 1.1 & 0.5 & 0.0 & 0.0 & 0.4 \\
\hline Jharkhand & 0.5 & 0.6 & 0.0 & 0.3 & 0.0 & 0.4 \\
\hline J \& K & 0.0 & 1.1 & 0.3 & 0.3 & 0.2 & 0.4 \\
\hline Karnataka & 1.8 & 1.1 & 1.2 & 0.5 & 0.1 & 0.9 \\
\hline Kerala & 0.0 & 1.1 & 0.7 & 0.2 & 0.1 & 0.3 \\
\hline Madhya Pradesh & 0.8 & 1.0 & 1.1 & 1.1 & 0.0 & 0.8 \\
\hline Maharashtra & 3.4 & 2.5 & 2.2 & 1.3 & 0.4 & 1.7 \\
\hline Manipur & 3.2 & 0.9 & 0.6 & 0.0 & 0.2 & 0.5 \\
\hline Meghalaya & 0.0 & 0.2 & 0.1 & 0.0 & 0.3 & 0.1 \\
\hline Mizoram & 0.0 & 0.0 & 1.8 & 0.4 & 0.2 & 0.6 \\
\hline Nagaland & 1.3 & 1.5 & 0.4 & 0.5 & 0.3 & 0.7 \\
\hline Odisha & 4.0 & 3.1 & 2.1 & .8 & 0.0 & 2.9 \\
\hline Punjab & 3.5 & 2.5 & 1.3 & 1.6 & 0.4 & 1.2 \\
\hline Rajasthan & 2.8 & 2.4 & 3.1 & 1.0 & 1.2 & 2.3 \\
\hline Sikkim & 0.0 & 1.5 & 0.2 & 0.0 & 0.0 & 0.3 \\
\hline Tamil Nadu & 1.6 & 0.1 & 0.2 & 0.3 & 0.2 & 0.4 \\
\hline Tripura & 1.6 & 1.0 & 1.0 & 0.0 & 0.0 & 0.9 \\
\hline Uttar Pradesh & 2.5 & 2.2 & 1.8 & 1.0 & 0.4 & 1.9 \\
\hline Uttaranchal & 0.0 & 1.1 & 0.3 & 0.3 & 0.0 & 0.3 \\
\hline West Bengal & 2.3 & 1.5 & 1.0 & 1.6 & 0.4 & 1.6 \\
\hline India & $\mathbf{2 . 0}$ & $\mathbf{1 . 6}$ & $\mathbf{1 . 2}$ & $\mathbf{0 . 7}$ & $\mathbf{0 . 2}$ & $\mathbf{1 . 2}$ \\
\hline & & & & & &
\end{tabular}

Table F. School Attendance as "Left school 2+ years ago" Linked with Poverty Status by States

\begin{tabular}{|c|c|c|c|c|c|c|}
\hline \multirow{2}{*}{ Name of states/UTs } & \multicolumn{5}{|c|}{ Wealth index } & \multirow[b]{2}{*}{ Total } \\
\hline & Poorest & Poorer & Middle & Richer & Richest & \\
\hline Andhra Pradesh & 11.5 & 8.6 & 7.9 & 3.4 & 0.7 & 6.4 \\
\hline Arunachal Pradesh & 7.2 & 3.6 & 3.1 & 4.3 & 4.0 & 4.5 \\
\hline Assam & 8.0 & 6.7 & 5.5 & 3.0 & 3.7 & 6.1 \\
\hline Bihar & 2.1 & 2.0 & 2.2 & 2.6 & 0.9 & 2.1 \\
\hline Chhattisgarh & 6.1 & 4.2 & 2.0 & 0.8 & 0.4 & 4.2 \\
\hline Delhi & 0.0 & 9.9 & 7.3 & 8.2 & 1.4 & 3.9 \\
\hline Goa & 9.2 & 5.1 & 5.5 & 3.2 & 2.0 & 3.3 \\
\hline Gujarat & 6.2 & 8.1 & 8.3 & 5.8 & 2.0 & 5.8 \\
\hline Haryana & 4.8 & 8.4 & 4.9 & 3.9 & 1.5 & 4.3 \\
\hline Himachal Pradesh & 0.0 & 4.2 & 1.1 & 0.0 & 0.3 & 0.9 \\
\hline Jharkhand & 7.6 & 8.3 & 4.4 & 7.0 & 4.7 & 7.1 \\
\hline $\mathrm{J} \& \mathrm{~K}$ & 4.3 & 5.1 & 4.8 & 3.6 & 4.5 & 4.5 \\
\hline Karnataka & 10.6 & 8.4 & 4.1 & 4.3 & 2.3 & 5.9 \\
\hline Kerala & 6.1 & 4.5 & 2.8 & 1.0 & 2.4 & 2.1 \\
\hline Madhya Pradesh & 3.1 & 4.1 & 3.4 & 3.4 & 0.8 & 3.2 \\
\hline Maharashtra & 7.8 & 5.6 & 4.2 & 1.9 & 1.5 & 3.7 \\
\hline Manipur & 4.8 & 2.9 & 1.2 & 1.1 & 0.7 & 1.6 \\
\hline Meghalaya & 6.1 & 4.8 & 6.8 & 5.6 & 2.7 & 5.5 \\
\hline Mizoram & 9.3 & 7.5 & 2.8 & 2.0 & 1.2 & 2.6 \\
\hline Nagaland & 2.6 & 2.7 & 2.2 & 1.7 & 1.9 & 2.2 \\
\hline Odisha & 5.6 & 4.3 & 3.5 & 1.4 & 0.7 & 4.2 \\
\hline Punjab & 1.8 & 7.9 & 6.7 & 3.1 & 2.5 & 3.9 \\
\hline
\end{tabular}




\begin{tabular}{l|l|l|l|l|l|l}
\hline Rajasthan & 4.3 & 4.2 & 3.4 & 2.7 & 1.5 & 3.4 \\
\hline Sikkim & 2.4 & 1.9 & 4.1 & 2.0 & 3.8 & 3.1 \\
\hline Tamil Nadu & 4.2 & 3.3 & 3.0 & 2.6 & 0.3 & 2.7 \\
\hline Tripura & 4.9 & 1.0 & 2.7 & 1.2 & 3.4 & 2.4 \\
\hline Uttar Pradesh & 4.2 & 3.3 & 3.6 & 2.8 & 0.5 & 3.3 \\
\hline Uttaranchal & 7.0 & 3.5 & 1.9 & 4.1 & 1.4 & 3.0 \\
\hline West Bengal & 6.2 & 6.0 & 3.5 & 2.8 & 1.9 & 4.8 \\
\hline India & $\mathbf{5 . 4}$ & $\mathbf{4 . 8}$ & $\mathbf{4 . 0}$ & $\mathbf{3 . 0}$ & $\mathbf{1 . 7}$ & $\mathbf{3 . 8}$ \\
\hline
\end{tabular}

